it is first given to volunteers. ${ }^{12-14}$ The drawback with all approaches made is that they have been based on the use of complex organisms and not pure antigens. Other than one parasite protein that has been found to protect ducks against $P$ lophurae, ${ }^{15}$ few data are available from research in vivo to indicate whether single antigens could be of value. Fortunately, attention is now being directed to the use of monoclonal antibodies to identify immunogenic antigens in malaria parasites, and several have recently been described both in rodent parasites ${ }^{16}$ and in $P$ falciparum. ${ }^{17}$ Future efforts will probably be focused on the application of this new technology and the production of protective sporozoite or merozoite antigens by DNA recombinant procedures. Indeed, this is the most likely route to a practical vaccine for use in man. There is, however, a long way to go, and we should be deceiving ourselves if we believed that a vaccine was, as some have suggested, just round the corner. It would also be a great mistake to assume that malaria will ever be controlled in whole populations (as distinct from individuals) by any single measure. Control programmes need to take into account the best available antivector measures, drugs, vaccines (including, perhaps, an antigamete component to interrupt further transmission $\left.{ }^{18}\right)$, and health education tailor made for any given area. The biggest need may still be for well-trained malariologists.

${ }^{1}$ Wernsdorfer W. The importance of malaria in the world. In: Kreier JP, ed. Malaria. Vol 3. Epidemiology, chemotherapy, morphology, and metabolism. London: Academic Press, 1890:1-93.

2 World Health Organisation. WHO Expert Committee on Malaria, 17th Report. Geneva: WHO, 1979. (Technical Report Series 640.)

${ }^{3}$ Public Health Laboratory Service. Malaria in the United Kingdom: 1980.
Colindale: Communicable Disease Surveillance Centre, 1981:1. (Communicable Disease Report CDR 81/13.)

United Nations Development Programme/World Bank/World Health Organisation. Special programme for research and training in tropical diseases. Fourth annual report. 1 fuly 1979-30 fune 1980. Geneva: 1980.

Cohen S. Immunity to malaria. Proc R Soc Lond (B) 1979;203:323-45.

'Cochrane AH, Nussenzweig RS, Nardin EH. Immunisation against sporozoites. In : Kreier JP, ed. Malaria. Vol 3. Immunology and immunisation. London: Academic Press, 1980:163-202.

Clyde DF, McCarthy V, Miller RM, Woodward WE. Immunisation of man against falciparum and vivax malaria by use of attenuated sporozoites. Am F Trop Med Hyg 1975;24:397-401.

${ }^{8}$ Rieckman KH, Beaudoin RL, Cassells JS, Sell KW. Use of attenuated sporozoites in the immunisation of human volunteers against falciparum malaria. Bull WHO 1979;57 :suppl 1:261-5.

9 Trager W, Jensen JB. Cultivation of erythrocytic and exoerythrocytic stages of plasmodia. In: Kreier JP, ed. Malaria. Vol 2. Pathology, vector studies, and culture. London: Academic Press, 1980:271-319.

${ }^{10}$ Siddiqui WA. Immunisation against asexual blood-inhabiting stages of plasmodia. In: Kreier JP, ed. Malaria. Vol 3. Immunology and immunisation. London: Academic Press, 1980:231-62.

${ }^{11}$ Desowitz RS, Miller LH. A perspective on malaria vaccines. Bull WHO $1980 ; 58: 897-908$.

${ }^{12}$ McGregor IA. Basic considerations concerning field trials of malaria vaccines in human populations. Bull WHO 1979;57,suppl 1:267-71.

${ }^{13}$ Diggs CL. Prospects for development of vaccines against Plasmodium falciparum infection. In: Kreier JP, ed. Malaria. Vol 3. Immunology and immunisation. London: Academic Press, 1980:299-315.

${ }^{14}$ Anonymous. Summary of plenary and working group discussions. The production and purification of malaria antigens in culture. Bull WHO $1979 ; 57$, suppl $1: 277-90$.

${ }^{15} \mathrm{Kilejian}$ A. Histidine-rich protein as a model malaria vaccine. Science 1978;201:922-4.

${ }^{16}$ Freeman RR, Trejdosiewicz AJ, Cross GAM. Protective monoclonal antibodies recognising stage-specific merozoite antigens of a rodent malaria parasite. Nature $1980 ; \mathbf{2 8 4}: 336-8$.

${ }^{17}$ Perrin LH, Ramirez E, Lambert PH, Miescher PA. Inhibition of $\mathbf{P}$ falciparum growth in human erythrocytes by monoclonal antibodies. Nature 1981;289:301-3.

${ }^{18} \mathrm{Gwadz}$ RW, Green I. Malaria immunisation in rhesus monkeys: a vaccine effective against both the sexual and asexual stages of Plasmodium knowlesi. F Exp Med 1978;148:1311-23.

\title{
Doctors' pay
}

In the 20 years since the Pilkington Royal Commission conceived the independent review body system for deciding NHS doctors' and dentists' pay ${ }^{1}$ governments have substantially interfered with recommended awards on two occasions, in $1966^{2}$ and $1970 .^{3}$ The $1981-2$ review $^{4}$ makes the third occasion and the first for a Conservative administration. The Government's decision to cut the Review Body's 9\% (average) recommended increase for doctors (p 1722) to $6 \%$ was given in person by the Prime Minister to the Chairman of Council of the BMA on 15 May. The reasons for this decision were published in a Parliamentary reply ( $p$ 1722). Doctors will have to judge whether these match up to Pilkington's declaration that "while the Government cannot abrogate its functions and responsibility for ultimate decisions, we are insistent that the recommendations of the Review Body must only very rarely and for most obviously compelling reasons be rejected." The Government's determination to control inflation and reduce spending in the public sector is well known. To achieve this end it has among other actions modified the outcome of the "Top salaries" review and resisted the civil servants' pay claim for nearly three months. In declaring its intention to hold doctors' pay within the NHS's $6 \%$ cash limits the Government has implied that to do otherwise would affect services to the patients. Even so, many doctors will be worried by contradictions in the Government's approach to the whole question of public sector pay and by the fact that in its report the Doctors' and Dentists' Review Body took into account "national economic considerations," including the NHS's 6\% cash limits.

The Review Body's chairman, Sir Robert Clark, and his colleagues appear to have taken the Government's decision stoically and are still in place, which should encourage the profession to "consider the Government's decision ... in a responsible manner," as the BMA's statement ( $p$ 1723) after the meeting with the Prime Minister put it. As to the report it would be a pity if in any arguments about the final outcome of the award the contents were relegated to history, for, while parts will not please doctors, there is much useful analysis and valuable comment in what is a clearly written document. The authors have obviously thought carefully about the profession's remuneration, expenses, and pensions, as well as analysing in the introduction one difficult general aspect of their task-namely, the "overlap" between their function as an independent body "charged with making recommendations for the whole remuneration structure" and the function of the profession's representatives and the Health Departments in negotiating changes in contractual terms and conditions of service. "Cases arise," states the report, "where the professions and the departments, although agreed on the desirability of a change, do not agree on its likely cost, on whether the cost should be offset or 'new money' provided, or on the way in which offsetting (if agreed) should be achieved." In proposing 
an early warning system on prospective agreements "to avoid exaggerated expectations on the part of the professions or the departments," the Review Body warns, however, that it does not contemplate participating in negotiations. This seems such an eminently sensible approach it is surprising that it has not been adopted befcre, given the recurrent problems over differing interpretations of "agreements."

In its evidence the BMA emphasised doctors' increasing work load and once again warned about the long hours that junior doctors are working. The Review Body has doubts about this claimed increase in work load. Indeed, in some searching paragraphs on general practitioners' deputising services, it states that "the growth in deputising services has acted as one counterbalancing factor to any increased work load in other areas of GMPs' work." On the hospital side we read that "the numbers of hospital doctors and dentists have increased, leading to a marked decline in individual work load (by 13-18\%)." The report admits, however, that the broad indicators used are "not a guide to either the quality of service provided or the demands of particular cases." Work load throughout the profession is a matter the Review Body intends to examine more closely in its next review, along with the operation of the $10 \%$ limit for private practice by whole-time consultants, introduced as part of the 1980 contract improvements. The Office of Manpower Economics (which services the Review Body), will also be conducting a study of the work and responsibilities of the training grades, for the Review Body shares "the juniors' deep concern over excessive hours." Such a study is urgent because according to the report the average number of contracted hours for doctors in training is still high -almost 90 hours a week. The outcome could be a major factor not only in judging appropriate rates of pay for excessive hours but also in planning the manpower and staffing structure of the hospital service. As the Review Body says unequivocally that one of its major concerns is "to ensure that work load ... is properly rewarded" the profession should inject some constructive ideas of its own at an early stage of any survey on what by general agreement is a complex subject.

Another important general topic dealt with in the Eleventh Report is the concept of the total remuneration package. "This," the report explains, "comprehends not only direct pay, but pensions and 'fringe benefits.' "The Review Body does not, however, directly concern itself with the level of private practice earnings, though it does "take account of the level of commitment to the NHS job...." It asked the Government Actuary to evaluate doctors' pension arrangements and the result appears in a 17-page appendix. The main findings were that the value of the doctors' pension scheme is noticeably greater than the value of outside schemes at comparable levels. Expressed as a percentage (net of employees' contributions) of career earnings, the value of a pension for a consultant with a $\mathrm{C}$ distinction award is about $16.5 \%$ compared with $6.5 \%$ or less for someone in a typical private sector scheme. After taking account, however, of fringe benefits in the private sector-equivalent to some $7-8 \%$ of the annual income of an established doctor-a doctor in a career post is probably level pegging with his comparative salary earner elsewhere.

General practitioners will receive one surprise benefit that may to some extent offset their disappointment with the
Government's intended cut of their net remuneration. Because of changes in the data base used in the complex calculations to determine the reimbursement of indirect practice expenses $\frac{\$}{\Phi}$ and the Review Body's aim to "ensure that there is no persis- $\frac{}{c}$ tent tendency to under- or overpayment, taking one year with another" some adjustments have been necessary and these expenses, which would not be affected by the Govern-D ment's $6 \%$ ceiling, have been raised by an average of $24.08 \%$, well above the current annual level of inflation. This year for the first time payments for contraceptive services are: to be included in average net remuneration. This change will not affect the overall income of GPs - the Review Bodyo proposed a rise in income for these services from around $£ 660$ 을 to about $£ 675$-and has been done because $95 \%$ of them $\frac{\bar{\sigma}}{\sigma}$ undertake such services for their patients. In making recom- $\varrho$ mendations for doctors in community medicine the Review Body has adopted a wait-and-see approach to the pay of $\overrightarrow{0}$ district community physicians who will be appointed in the reorganised NHS. The profession's request, supported by the $\vec{\sigma}$ DHSS, that they should be paid on the same basis as existing area medical officers has been turned down as there are "a number of uncertainties as to the work and responsibilities of DMOs."

To return, however, to the principal issues facing doctors on this 1981-2 award. What effect would a $6 \%$ ceiling have on it: and what practical steps do the profession's representatives of now take? In his press conference after the BMA's meeting with the Prime Minister, the Secretary, Dr J D J Havard, said that if a $6 \%$ limit was imposed the profession would $\omega$ expect it to maintain the relativities recommended by the Review Body. (Examples of the likely resultant increases are given at $\mathrm{p}$ 1724.) Junior doctors have already given notice- $\bullet$ before the report was published-of their concern over any. Government interference with the award. ${ }^{5}$ But the first indication of the profession's attitude to the Government's plan will have come from a meeting of chairmen of craft committees called by the Chairman of Council for 20 May-after the $B M \mathcal{F}_{\mathcal{D}}^{\circ}$ has gone to press. After that the craft committees, or their $\varrho$ negotiating subcommittees, will consider the position. If the $\overrightarrow{\overrightarrow{0}}$ profession is to receive any increases reasonably promptly the $\frac{3}{5}$ various crafts, whose representative committees have autonomous powers, will need to make their decisions within the next three weeks or so. The nature of their decisions will presumably depend on soundings of their constituents.

Politically realistic doctors will probably acknowledge that in present circumstances any improvement on $6 \%$ is unlikely, particularly as the Prime Minister has-showing political adroitness-reminded the public about last year's sizable 음 catching-up award. But if the profession's representatives $N$ acquiesce in the Government's plans they will do so only if $\rightarrow$ they are convinced that this is not the first step in another financial decline for doctors that will eventually have to be rectified by another substantial updating exercise.

${ }^{1}$ Royal Commission on Doctors' and Dentists' Remuneration, 1957-60. Report. Cmnd 939. London: HMSO, 1960.

${ }^{2}$ Anonymous. A fresh start. Br Med $\mathcal{F}$ 1966;i:1183-5.

3 Anonymous. Independence at stake. Br Med $\mathcal{F} 1970$;ii:615-6.

${ }^{4}$ Review Body on Doctors' and Dentists' Remuneration. Eleventh report. Cmnd 8239. London: HMSO, 1981.

5 Anonymous. Br Med f 1981 ;282:1489-90. 